REPORTS OF MORPHOLOGY
$\begin{gathered}\text { Official Journal of the Scientific Society of Anatomists, } \\ \text { Histologists, Embryologists and Topographic Anatomists } \\ \text { of Ukraine } \\ \text { journal homepage: https://morphology-journal.com }\end{gathered}$

\title{
Morphofunctional changes of structural components of masticatory muscles of mature animals in mercazolilum-induced hypothyroidism
}

Sahan N.T.

Ivano-Frankivsk National Medical University, Ivano-Frankivsk, Ukraine

\section{ARTICLE INFO}

Received: 20 September, 2018

Accepted: 15 October, 2018

UDC: $616.742+616-092.9+616.441-$ 008.64

\section{CORRESPONDING AUTHOR}

e-mail: antimis2012@gmail.com Sahan N.T.

\begin{abstract}
The damage of the muscular system is one of the frequent complications in thyroid diseases, but today there is no unanimous view on the morphofunctional changes in masticatory muscules in hypothyroidism. The purpose of this study was to determine the peculiarities of the structural organization of the masseter and lateral pterygoid muscles of mature rats in various stages of experimentally modeled hypothyroidism. The study was performed on the masticatory muscles of mature male rats during the $14^{\text {th }}, 21^{\text {th }}, 28^{\text {th }}$ days of the development of mercazolilum-induced hypothyroidism. The following research methods were used: injection method of study of the circulatory bed of the masticatory muscles; histological examination of blood vessels and tissue elements of the masticatory muscles; electron microscopic examination; morphometric analysis (mean value of blood vessels' lumen and thickness of their walls; number of capillaries in $1 ? \mathrm{~m}^{2}$ of cross section of muscular fiber; the quantity of the capillaries at one muscular fiber, the percentage of oxidative (OMF), oxidative-glycolytic (OGMF), glycolytic (GMF) muscular fibers, average muscular fiber area, biochemical methods, and statistical analysis was conducted out using the software RV.3.0. The development of hypothyroidism is indicated by the reduction of hormones of the thyroid gland in the blood. During the $14^{\text {th }}$ day of the experiment in the arterial bed in the injection of Parisian blue in the masticatory muscles there is a deformation of the vascular pattern. The number of hemocapillaries decreases. The edema of the cytoplasm of endothelial cells is submicroscopically marked. In muscular fibers, the cross-striation is broken, the area of their crosssection is enlarged, the dilation and vacuolization are observed in the endomysium. $A$ change was determined in the quantitative distribution of all types of fibers (the number of OGMF and OMF decreased, and the amount of GMF increased). At the ultramicroscopic level, there were observed pronounced changes in all types of muscular fibers, especially in the GMF and OMF of the masseter muscle. On the $21^{\text {st }}$ day, a significant deformation of the vascular pattern was observed, with a decrease of the arterial lumen and an increase of the vein lumen. The number of hemocapillaries continues to decrease. Ultra-structurally, in the endothelial cells of the hemocapillaries of the masticatory muscles, edema changes progress. In muscular fibers there is a loss of cross-striation and observed swelling. There is a tendency to decrease of the number of OGMF and OMF and increase of the amount of GMF. At the ultramicroscopic level, there are pronounced changes in all types of fibers, especially in the masseter muscle. During the $28^{\text {th }}$ day of mercazolilum-induced hypothyroidism changes in the vessels and muscle fibers are progressing. Described morphological changes are associated with the dynamics of the trace substances' composition. Thus, in mercazoliluminduced hypothyroidism in the masticatory muscles there are edematous changes both in the vascular bed and in muscular fibers. Moreover, the changes are deepened depending on the duration of the experiment.
\end{abstract}

Keywords: hypothyroidism, muscular fiber, ontogenesis, hemomicrocirculatory bed.

\section{Introduction}

The study of the morphology of masticatory muscles was performed for a long time by many native and foreign scholars $[8,16,17,21,22,23,29]$. However, there is no clear and unanimous point of view of the morphology of 
these muscles. The study of masticatory muscles under the influence of various factors, including the changes of the thyroid status are of particular relevance. Damage of the muscular system is one of the most frequent complications in diseases of the thyroid gland. An overview of scientific literature showed that $5 \%$ of all myopathies are associated with pathology of the thyroid gland $[9,14,15$, $20,24,29,30]$. Deficiency of thyroid hormones results in a violation of the expression of the heavy chain myosin genome, redistribution of its isoforms, inhibition of protein synthesis and, consequently, muscular growth. Besides, in the deficiency of hormones of the thyroid gland, the mobilization of free fatty acids from adipose tissue is disturbed, which leads to the insufficient lipid delivery to the skeletal muscles and is a possible cause of muscular weakness and reduced ability to work [1, 6, 31].

Taking into account the topicality of this issue and the constant increase and spread of morbidity (in Ukraine, as of January 1, 2012, there were registered 90.884 thousand patients with hypothyroidism (in 1999 - 53 thousand); the incidence rate in 2011 was 22.1 per 100.000), the study of the morphofunctional state of masticatory muscles in hypothyroidism requires further study.

Thus, the aim of our study is to establish the peculiarities of the structural organization of the masseter and lateral pterygoid muscles of the mature rats at various stages of experimentally modeled hypothyroidism.

\section{Materials and methods}

The material for the study was masseter and lateral pterygoid muscles of the 48 white outbred mature male rats. The material was taken in clearly defined symmetrical places of the masseter and lateral pterygoid muscles during the $14^{\text {th }}, 21^{\text {th }}, 28^{\text {th }}$ days of experimentally modeled hypothyroidism. Animals were divided into groups: group I - intact (12 animals), which were kept under normal conditions of vivarium using natural for rodent feeding; group II - under the conditions of mercazolilum-induced hypothyroidism (36 animals).

Maintenance of animals, their nutrition and manipulations with them were performed in compliance with ethical and legislative norms and requirements during the implementation of scientific and morphological studies, in accordance with the provisions of the "European Convention for the Protection of Vertebrate Animals used for the experiments and other scientific purposes" (Strasbourg, 1986), Appendix 4 to the "Rules for the performance of the works using experimental animals", approved by the Order of the Ministry of Health of Ukraine №755 of 12.08.1997, the Helsinki Declaration of the World Medical Association (2000), "On Measures as to Further Improvement of the Organization of Forms of Work with the Use of Experimental Animals" and the provisions of the "General Principles of Animal Experiments" taken by the First National Congress on Bioethics (Kyiv, 2001); in accordance with the Law of Ukraine №3447-IV "On the
Protection of Animals from Cruel Treatment" of 21.02.2006 (Expert Opinion of the Bioethics Commission of IvanoFrankivsk National Medical University, Protocol №104/18 dated October 25, 2018).

Euthanasia of animals was performed by intraperitoneal administration of sodium thiopental ( $2 \%$ solution of sodium thiopental in a dose of $25 \mathrm{mg} / \mathrm{kg}$ ).

The following research methods were used: modeling of mercazolilum-induced hypothyroidism [19, 7]; injection method of study of the circulatory bed of the masticatory muscles ("Parisian blue"); histological examination of blood vessels and tissue elements of the masticatory muscles (coloring with hematoxylin and eosin, fuchsin according to Hart, trichrome staining according to Masson, hematoxylinmain fuchsin-picric acid according to Van Gieson; the histochemical method of masticatory muscles studying (succinate dehydrogenase (SDG) according to M. Nachlas method); electron microscopic examination; morphometric analysis (mean value of blood vessels' lumen and thickness of their walls; number of capillaries in $1 \mu \mathrm{m}^{2}$ of cross section of muscular fiber; the quantity of the capillaries at one muscular fiber, the percentage of oxidative (OMF), oxidative-glycolytic (OGMF), glycolytic (GMF) muscular fibers, average muscular fiber area, biochemical methods, and statistical analysis.

Variational-statistical processing was carried out using the software RV.3.0. The data of the descriptive statistics is given as $M \pm m$ (selective average \pm standard deviation).

\section{Results}

Thyroid homeostasis in the dynamics of the induced hypothyroidism during the 14th day was: $T_{3}-2.68 \pm 0.23$ $n M / l(p<0.01), T_{4}-26.86 \pm 2.80(p<0.01) n M / l$. During the $21^{\text {st }}$ day: TSH $-0.08 \pm 0.01 \mathrm{ulU} / \mathrm{mL}(p<0.01), \mathrm{T}_{3}-2.56 \pm 0.26$ $n M / l(p<0.01), T_{4}-19.89 \pm 2.00(p<0.01) n M / l$. During the $28^{\text {th }}$ day of induced hypothyroidism: TSH $-0.07 \pm 0.01 \mathrm{ulU} /$ $\mathrm{mL}(\mathrm{p}<0.01), \mathrm{T}_{3}-2.61 \pm 0.25 \mathrm{nM} / \mathrm{l}(\mathrm{p}<0.01), \mathrm{T}_{4}-24.41 \pm 3.00$ $(p<0.01) n M / l$.

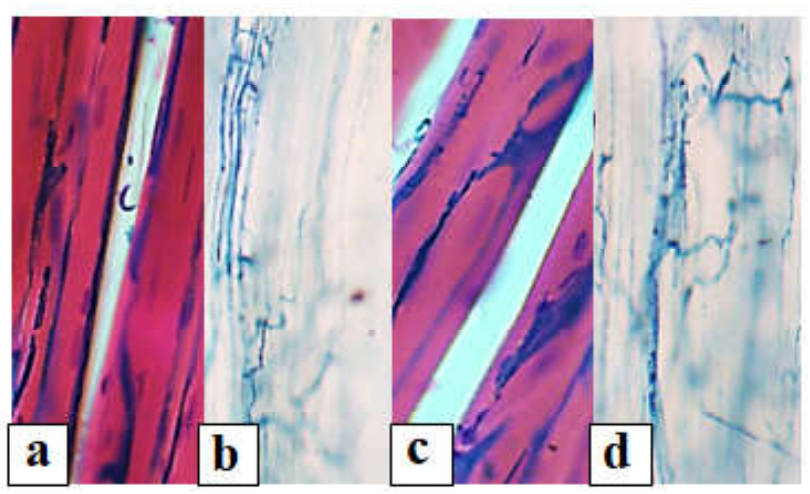

Fig. 1. Unevenness and mosaicity of the vascular pattern of the masseter $(a, b)$ and lateral pterygoid $(c, d)$ muscles of mature rats during the $14^{\text {th }}$ day of mercazolilum-induced hypothyroidism. Staining: a, c - injection with Parisian blue with additional coloring of hematoxylin and eosin; $b, d$ - injection with Parisian blue. Microphotograph. ocular lens $\times 10$, field lens $\times 20$. 

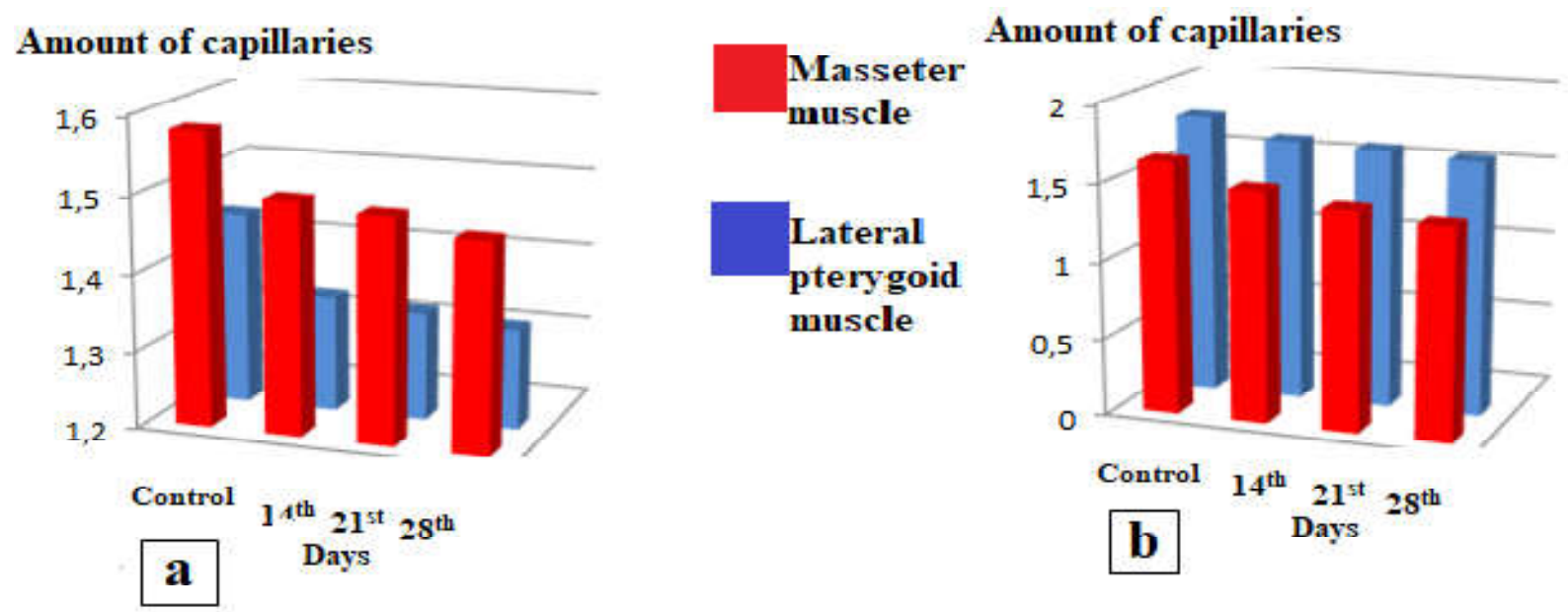

Fig. 2. Reduction of the number of hemocapillaries in $1 \mu \mathrm{m}^{2}$ (a) and the amount of hemocapillaries pertaining to one muscular fiber (b) in the masticatory muscles of mature animals at various stages of the development of mercazolilum-induced hypothyroidism.

During the 14th day of the experiment in the arterial bed of the mature rats in the injection of Parisian blue both in the masseter and lateral pterygoid muscles, a change of the vascular pattern (Fig. 1) is observed. The number of hemocapillaries decreases in comparison with the norm (Fig. 2).

In a submicroscopic study, there is observed the edema of the endothelial cells of the cytoplasm, which leads to the narrowing of the lumen and, subsequently, to the formation of erythrocytic sludges (Fig. 3). Hemocapillaries are surrounded by an electron-transparent basic substance.

In muscular fibers, cross-striation is much disordered. The nuclei of muscular fibers are enlarged and slightly lumenized. There is an expansion and vacuolization of endomysium between muscular fibers. Visually the perimysium is thickened and loose.

In the study of SDG activity, we have determined a change in the quantitative distribution of all types of fibers (the number of OGMF and OMF decreased and the amount of GMF increased (Fig. 4)). In addition, muscular fibers have been altered and deformed. SDG was unevenly distributed.

Morphometric study reveals a certain increase in the cross-sectional area of all types of fibers in comparison with the norm (Fig. 5). At the ultramicroscopic level, the pronounced changes were observed in all types of muscular fibers, especially in the GMF and OMF of the masseter muscle. A focal loss of cross-striation was noted, since isotropic disks (strip I) and anisotropic disks (strip A), Z-lines are deformed and disorganized. Mitochondria are enlarged, have a bright matrix and ruined crests (Fig. $6)$.

During the 21st day of the mercazolilum-induced hypothyroidism, there were determined a significant uneven filling of the vessels of the masseter and lateral pterygoid muscles with the injectable mass, resulting in the vascular pattern being deformed and mosaic (Fig. 7).

During histological examination, unevenness and deformation of vascular lumen are observed. The arterial
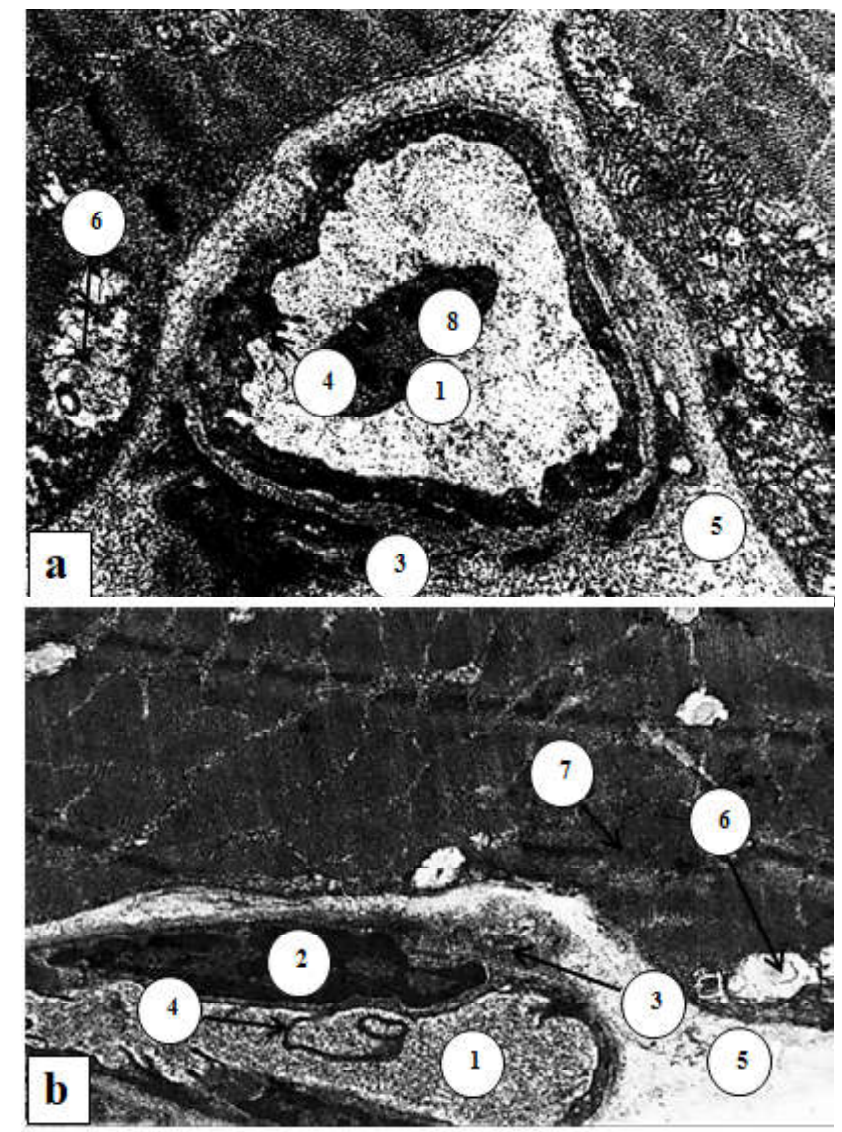

Fig. 3. The ultrastructural organization of the masseter (a) and lateral pterygoid (b) muscles of the mature rat during the 14th day of the development of mercazolilum-induced hypothyroidism. Electronic Microphotograph. 1 - deformed lumen of the hemocapillary, 2 - nucleus of the endothelial cell hemocapillary with marginally located heterochromatin and invaginations of the nuclear membrane, 3 - delaminatability of the basal membrane of the endothelial cell hemocapillary, 4 - cytoplasmic excrescences into the hemocapillary lumen, 5 - dilated and vacuolated perivascular space, 6 - destroyed mitochondria, 7 - violation of cross-striation, 8 - platelet. Magnification: $\times 8000$. 


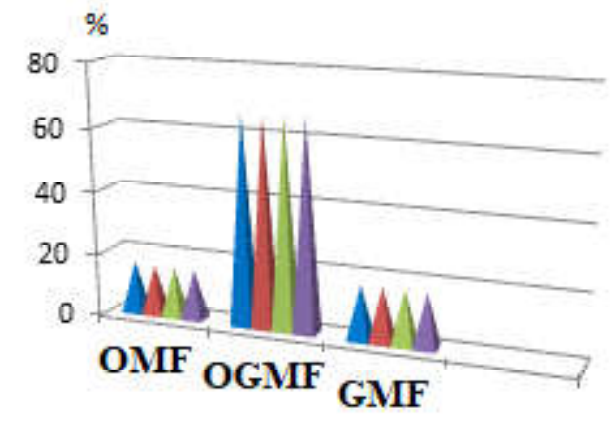

a

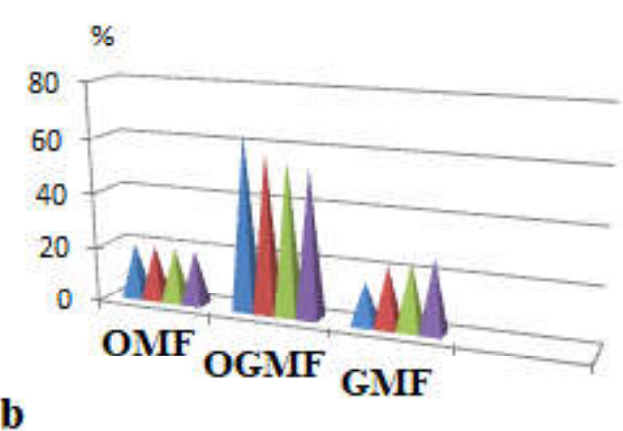

$21^{\text {st }}$ day $\square 28^{\text {th }}$ day

Fig. 4. Change of the quantitative composition of muscular fibers in the masseter (a) and lateral pterygoid (b) muscles of mature animals in different periods of experimental hypothyroidism.

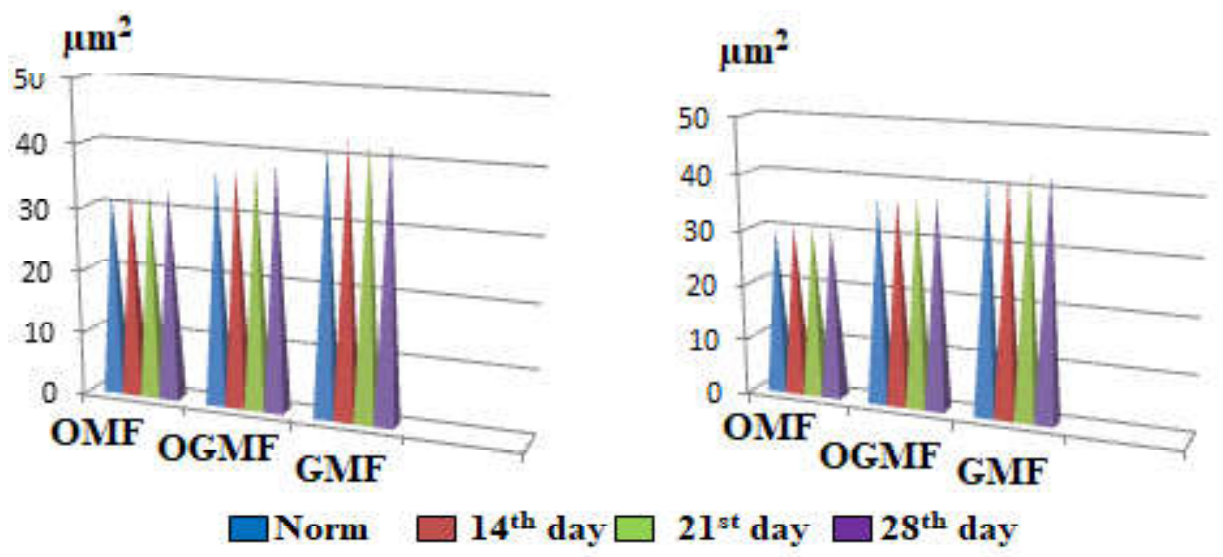

Fig. 5. Change of the cross-sectional area of muscular fibers in the masseter (a) and lateral pterygoid (b) muscles of mature animals at different terms of experimental hypothyroidism.

lumen decreases, compared with control, the venous lumen increases. The number of hemocapillaries in $1 \mu \mathrm{m}^{2}$ of the cross-section of muscular fibers continues to decrease. One muscular fiber also has a smaller amount of hemocapillaries, compared with the norm. Ultrastructurally it is found that there are edematous changes in endothelial cells of hemocapillaries of masticatory muscles. One can observe cytoplasmic excrescences into the lumen of the hemocapillary, indicating the development of hypoxia and disorder of the transcapillary exchange.

In muscular fibers there is a loss of cross-striation, edema of their nuclei, dilation, rupture and edematous changes of endomysium and perimysium with the formation of vacuoles (Fig. 8). During the morphometric study, an increase of the cross-sectional area of all types of fibers is observed (see Fig. 5). During the study of SDGactivity, there was determined some redistribution in the number of different types of muscular fibers, as well as their edematous changes and deformity (see Fig. 4).

At the ultramicroscopic level in the mature animals, there were marked changes in all types of fibers, especially in the masseter muscle, which were characterized by the loss of cross-striation, the destruction of isotropic (strip I) and anisotropic (strip A) discs, Z-lines. The nuclei in every muscular fiber are large, of lowered electron density, and their membrane forms profound invaginations. Mitochondria are of a sack-shaped form, have a bright matrix and destroyed crests (Fig. 9).

During the 28th day of mercazolilum-induced hypothyroidism in the arterial bed of the masseter and lateral pterygoid muscles of mature animals, one can observe the disorders and deformation of the vascular pattern, as a result of which it looks multiglomerular. In the injection with Parisian blue, the areas which are well and poorly filled with staining, are alternating (Fig. 10).

Among the intramuscular small arteries and arterioles one can find the closed ones, in which the paint does not fall. Morphometric study shows a significant narrowing of the arteries and thickening of the arterial wall, as well as the enlargement of the lumen and thinness of the venous wall, compared with the control. Significantly decreases the number of hemocapillaries in $1 \mu \mathrm{m}^{2}$ of the transverse section of muscular fiber (see Fig. 2).

During the ultramicroscopic examination of endothelial cells, an increase of edematous changes is observed. In muscular fibers, there was observed light-optically cross- 

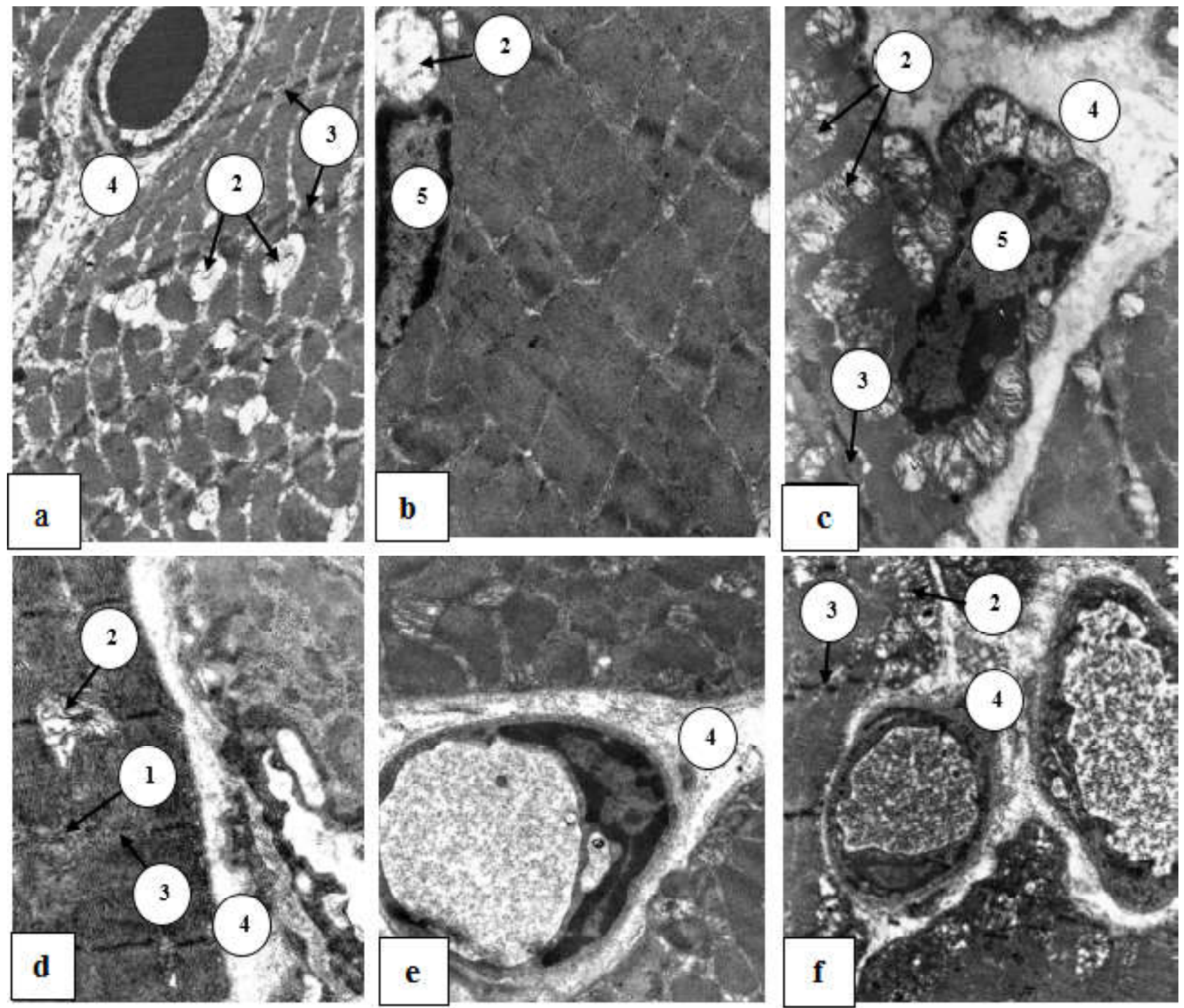

Fig. 6. Ultramicroscopic changes in the structure of the masseter (a, b, c) and lateral pterygoid ( $d, e, f)$ muscles of mature rat during the 14th day of the mercazolilum-induced hypothyroidism. Electronic Microphotography. 1 - loss of cross-striation of muscular fiber, 2 expanded and destroyed mitochondria, 3 expanded and destroyed Z-line, 4 - swollen endomysium, 5 - nucleus of the muscular fiber. Magnification: a - x4800; b, e - x8000; c, f - x6400, d - x12000.

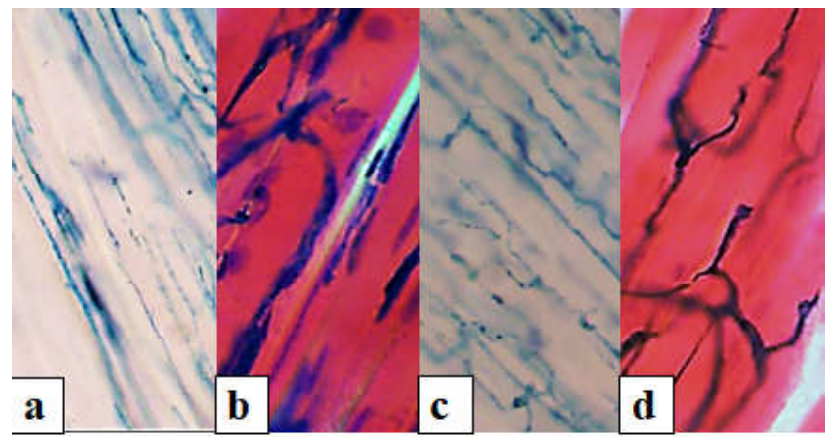

Fig. 7. Angioarchitectonics of the masseter $(a, b)$ and lateral pterygoid $(c, d)$ muscles of mature rats during the $21^{\text {st }}$ day of mercazolilum-induced hypothyroidism. Staining: a, c - injection with Parisian blue; $b, d$ - injection with Parisian blue with additional coloration of hematoxylin and eosin. Microphotograph. Ocular lens $\mathrm{x} 10$, field lens $\mathrm{x} 20$.

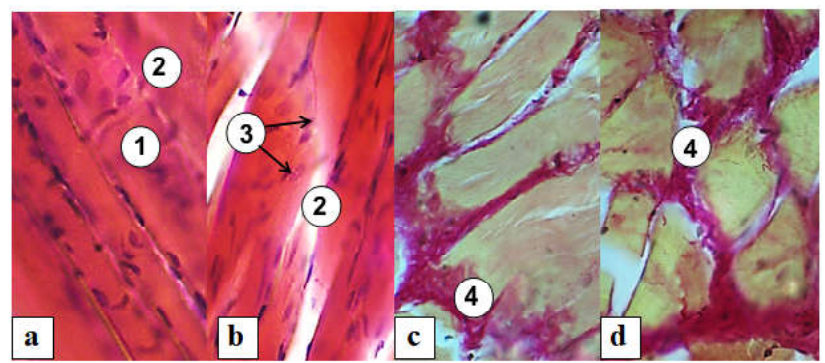

Fig. 8. Histostructure of the masseter (a) and lateral pterygoid (b) muscles of mature rats during the 21st day of experimental hypothyroidism. Staining: a, b - hematoxylin and eosin; c, d hematoxylin-main fuchsin-picric acid according to Van Gieson. Microphotograph. 1 - loss of cross-striation of muscular fibers, 2 - edema of muscular fibers, 3 - nuclei of muscular fibers, 4 dilation and edema of the intermuscular layers. Magnification: ocular lens $\times 10$, field lens $x 40$. 


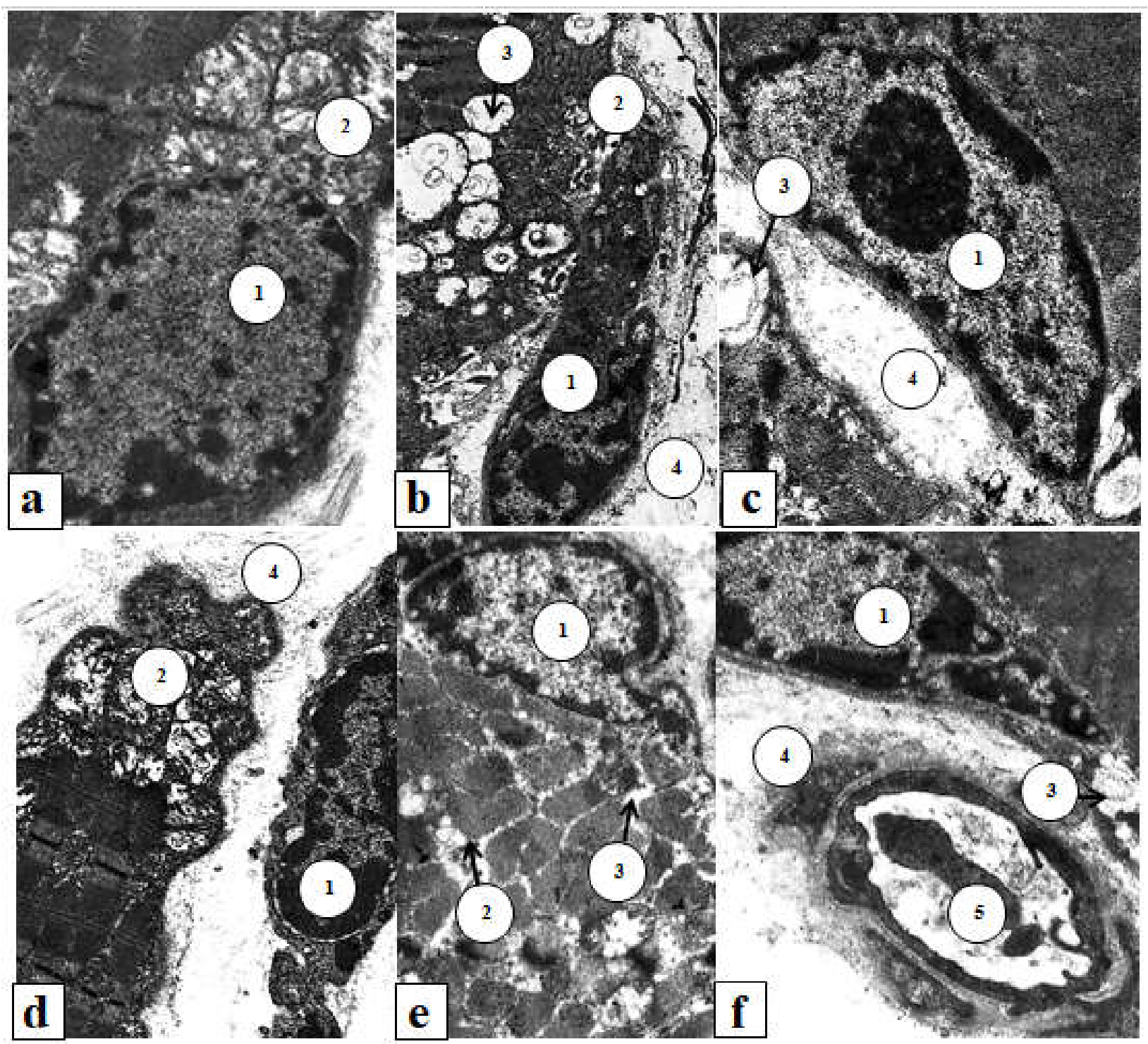

Fig. 9. Sub-microscopic changes in the structure of the masseter $(a, b, c)$ and lateral pterygoid $(d, e, f)$ muscles of mature rat during the $21^{\text {st }}$ day of mercazolilum-induced hypothyroidism. Electronic Microphotograph. 1 - nucleus of the muscular fiber with marginally placed heterochromatin, 2 - expanded and destroyed mitochondria, 3 - vacuolization of muscular fibers, 4 - swollen and disorganized connective tissue elements, 5 - hemocapillary. Magnification: a, c - x8000; b, e, f-6400; d-x9600.

striation loss, their vacuolization, dilation and vacuolization of endomysium and perimysium with the formation of vacuoles. In the morphometric study, an increase of the cross-sectional area of all types of fibers compared with the norm is noted (see Fig. 5).

In the study of SDG-activity, we have found that the number of OGMF and OMF decreases with the simultaneous increase of the amount of GMF (see Fig, 4). In this case, the fibers appear enlarged and deformed, the enzyme accumulates unevenly. At the ultramicroscopic level, marked edematous changes and destruction of structures, especially mitochondria, were observed in all types of fibers (Fig. 11).

Thus, in mercazolilum-induced hypothyroidism, in muscular fibers there are significant edematous changes both in the histological and ultrastructural levels. In the morphometric study, an increase of the diameter of all types of fibers was determined. Patients mostly suffer from GMF. Swelling and vacuolation of the connective tissue of the endomysium and perimysium are also noted. Moreover, the changes are deepened depending on the duration of the experiment. During study of the succinate dehydrogenase activity of muscular fibers, we've determined that there is a redistribution in the amount of muscular fibers. There is a tendency to decrease of OGMF and a significant increase of GMF.

Such morphological changes are associated with the dynamics of the microelement composition. Thus, the content of $\mathrm{Ca}, \mathrm{P}, \mathrm{Mg}$, during the $14^{\text {th }}$ day of the experiment was $1.94 \pm 0.19 \mathrm{mM} / \mathrm{l}(p<0.01) ; 29.97 \pm 3.07 \mathrm{mM} / \mathrm{l}(p<0.01)$, 


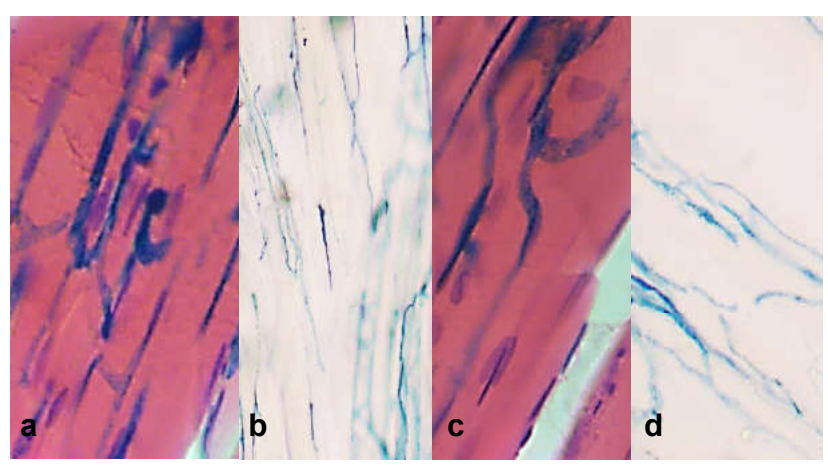

Fig. 10. Desolation and mosaicity of the vascular pattern of the masseter (a, b) and lateral pterygoid (c, d) muscles of mature rats during the $28^{\text {th }}$ day of mercazolilum-induced hypothyroidism. Staining: a, c - injection with Parisian blue with the addition of hematoxylin and eosin; b, d - injection with Parisian blue. Microphotograph. Magnification: ocular lens $\times 10$, field lens $\times 20$.

$1.42 \pm 0.17 \mathrm{mM} / \mathrm{l}(\mathrm{p}<0.01)$ respectively. During the $21^{\text {st }}$ day $-1.82 \pm 0.19 \mathrm{mM} / \mathrm{l}(p<0.01) ; 1.39 \pm 0.18 \mathrm{mM} / \mathrm{l}(p<0.01)$; during the $28^{\text {th }}$ day $-1.75 \pm 0.16 \mathrm{mM} / \mathrm{l}(\mathrm{p}<0.01) ; 22.70 \pm 2.49$
$\mathrm{mM} / \mathrm{I}(\mathrm{p}<0.01), 1.37 \pm 0.18 \mathrm{mM} / \mathrm{l}(\mathrm{p}<001)$, respectively.

\section{Discussion}

In hypothyroidism in the vascular bed of masticatory muscles during the 14th day there are significant changes. Our results are consistent with studies of the vascular bed in hypothyroidism [2, 3], where it was found that in patients with hypothyroidism there are sharply expressed violations in the system of terminal blood flow with the predominance of intravascular and vascular changes in the form of foci of microcongestion due to the increased blood viscosity, hematocrit, perivascular hemorrhages, perivascular edema, tortuosity of microvessels of all links of the microcirculatory bed, and "sludge" - a phenomenon in the capillaries. Further during the $21^{\text {st }}$ and $28^{\text {th }}$ day of the mercazolilum-induced hypothyroidism we observe the deepening of changes in the circulatory bed, which corresponds to studies [28], in which morphological changes in the circulatory bed of experimental animals become more significant, with the prolongation of experiment time.
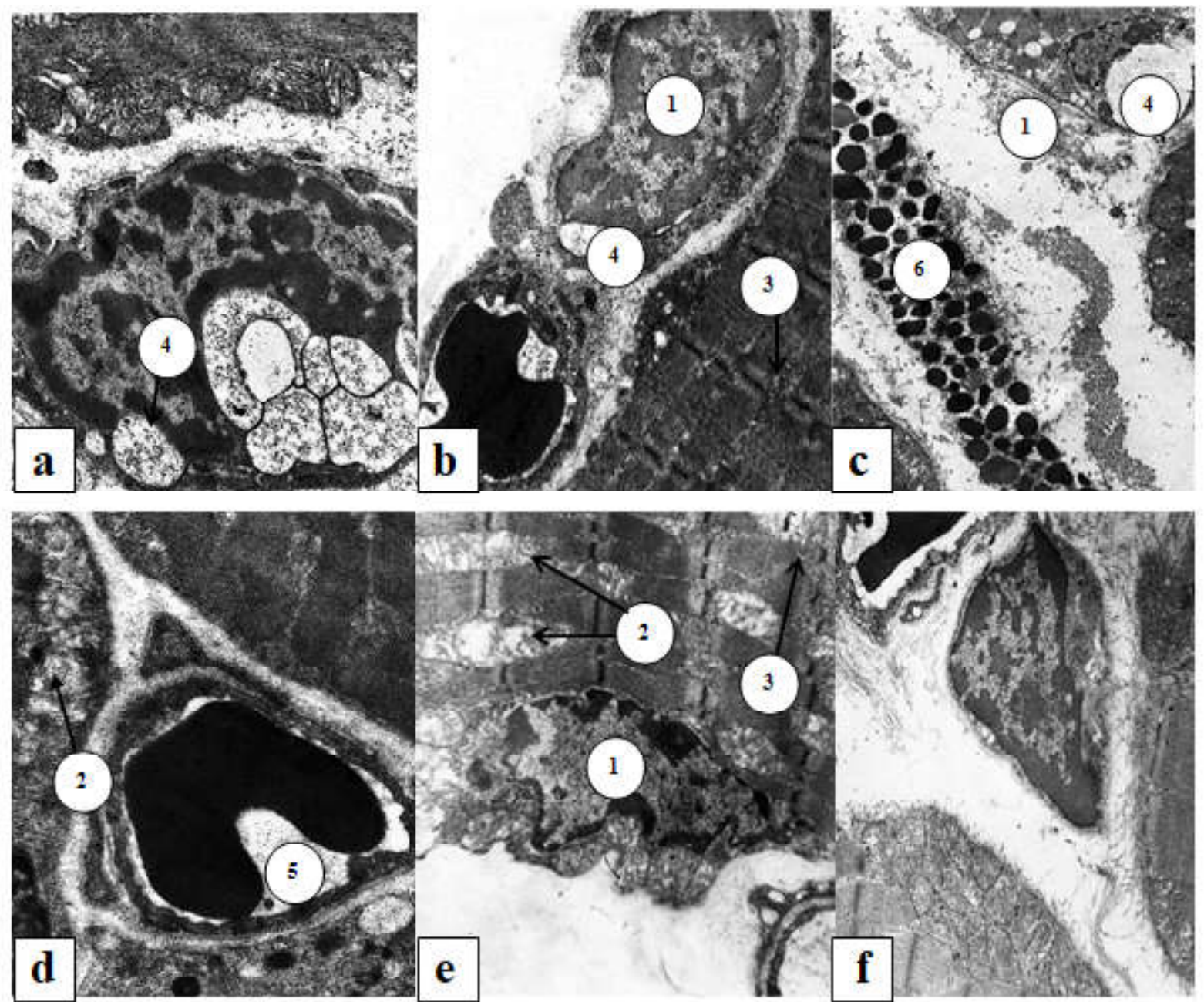

Fig. 11. Submicroscopic organization of the masseter muscle of mature rat during the 28 th day of mercazolilum-induced hypothyroidism. Electronic Microphotography. 1 - nucleus of muscular fiber; 2 - mitochondria with uncomplemented crests, 3 - disorganized striation, 4 vacuoles, 5 - hemocapillary, 6 - mastocyte. Magnification: a - x9600; b, c, d, e, f - x8000. 
Multiple studies are devoted to the study of the causes of changes in the vascular bed in hypothyroidism. Thyroid hormones have been found to induce 3-hydroxy-3methylglutaryl-coenzyme-A-reductase, which is the first step in the synthesis of cholesterol. Triiodothyronine also regulates the activity of receptors of low density lipoprotein, controlling the activity of their responsible genes and protects them from oxidation [11]. $T_{3}$ regulates the activity of cholesterol-7a-hydroxylase - key enzyme in the synthesis of bile acids, which in hypothyroidism conditions slows down the cholesterol, contributing to its increase in blood [25, 26]. It has been found that in hypothyroidism the concentration and activity of HDLLp-PLA2, which is associated with the anti-atherogenic effect of low density lipoprotein, decreases. Thus, in hypothyroidism, the level of cholesterol increases and there is a dyslipidemia that has an atherogenic nature and increases the risk of atherosclerosis [12, 10]. Perhaps, the development of atherosclerosis leads to further vascular damage.

Also, the disorders in the vascular bed of masticatory muscles in hypothyroidism could be attributed to the development of endothelial dysfunction and violation of relaxation of smooth muscular cells in vessels, which leads to an increase in peripheral vascular resistance. Some studies have described thickening of the intima-media complex in people with hypothyroidism [16].

In the study of muscular fibers during the $14^{\text {th }}, 21^{\text {st }}$ and especially $28^{\text {th }}$ days of experimental mercazolilum-induced hypothyroidism, one can note the increasing edematous changes in all types of muscular fibers, and especially in glycolytic ones, which confirms the opinion that the severity of morphological changes in somatic muscles depends on the duration of hypothyroidism, not on the severity and depth of the process [28]. Our studies are consistent with others, which determined that fast muscular fibers are much more likely to be damaged than slow ones [27]. They believe, that this is due to the thinner Z- and M-discs. Biochemically, it was found that in the case of muscular damage, the concentration of "fast" myosin in the blood is twice that of "slow" one, which indicates more violations of the structure of the corresponding muscular fibers [13]. Significant edema can be observed in the connective tissue components of the endo- and perimysium, the diffuse accumulation of glycoproteins, which is the determining factor of exudation. Initial manifestations of experimental hypothyroidism were detected during the $14^{\text {th }}$ day, the full picture - during the $28^{\text {th }}$, and during the $60^{\text {th }}$ day - the day when in studied structure the severe structural changes with necrosis were determined. The acuteness of inflammation was

\section{References}

[1]Alexander, E. K., Pearce, E. N., Brent, G. A., Brown, R. S., Chen, H., Dosiou, C., ... Sullivan, S. (2017). Guidelines of the American Thyroid Association for the Diagnosis and Management of Thyroid Disease During Pregnancy and the Postpartum. Thyroid, 27(3), 315-389. doi: 10.1089/thy.2016.0457.

[2] Arslanbekova, A. Ch., Abusuyev, S. A., \& Magomedov, M. A. characterized by inflammatory polymorphic cellular infiltrate with a high content of neutrophilic granulocytes, as well as an exudative component that occurs as a result of accumulation in glycoproteins tissues. At the same time, chromotropic substances are released from the bonds with proteins and are accumulated mainly in the intermediate substance, followed by the replacement of collagenous fibers with mucus-shaped masses. Infiltrate accumulates in large quantities in the intermediate substance, as a result there is a compression of cells, dystrophy, necrobiosis, necrosis and atrophy.

The cross-sectional area in all types of muscular fibers increases. These changes are described as "pseudohypertrophy" in Kocher-Debre-Semelaigne syndrome in hypothyroidism in children. It is accompanied by an increase of muscular fibers, but not of the increase of muscular strength, but rather a decrease of muscular strength and the development of muscular hypotonia [5]. Reduction of the muscular power of skeletal muscles in hypothyroidism may be due to the unconventional effects of $T_{4}$ at the structural and functional characteristics of the membranes, including the membrane of the sarcoplasmic reticulum. In this case, both lipid and protein component of the "liquid" bilayer is changing. This reduces the activity of $\mathrm{Ca}^{2+} \mathrm{ATP}$ ase and decreases the rate of absorption of calcium ions [18]. Changes of muscles in hypothyroid myopathy are characterized by their increase and induration. Patients often complain of muscular soreness in the palpation and movements. The slowing down of the contraction and relaxation of the muscles is characteristic for pseudomyotonic syndrome, which is not accompanied by a violation of electrical conductivity [4].

The performed morphofunctional research is the theoretical basis for the development and pathogenetic substantiation of measures aimed at correction and prevention of the development of iodine deficiency disorders, which, in turn, will lead to the prevention and reduction of the level of morbidity, its complications, disability and mortality caused by them.

\section{Conclusions}

In mercazolilum-induced hypothyroidism in the masticatory muscles there are edematous changes both in the vascular bed and in muscular fibers. Patients suffer mostly from GMF. Swelling and vacuolation of the connective tissue of the endomysium and perimysium are also observed, which is confirmed by both histological and submicroscopic studies. Moreover, the changes are deepened depending on the duration of the experiment.

(2007). Morphofunctional analysis of microcirculation after complex treatment using interval hypoxytherapy 17 of primary hypothyroidism. Morfologicheskiye vedomosti, 3(4), 85-87.

[3] Arslanbekova, A. Ch., Abusuyev, S. A., \& Magomedov, M. A. (2007). The state of microcirculatory hemodynamics after complex treatment using interval hypoxytherapy of primary 
hypothyroidism. Ural Medical Journal, 12(40), 53.

[4] Bodnar, P. M. (2010). Endocrinology. Vinnitsa: Nova knyha.

[5] Bogova, E. Ya., \& Shyriaeva, T. Yu. (2017). Pseudohypertrophic myopathy in hypothyroidism in a child (Kocher-DebreSemelaigne syndrome). Problemy endokrinologii, 63(2), 121123. doi: $10.14341 /$ probl2017632121-123.

[6] B?lling, T., Geisenheiser, A., Pape, H., Martini, C., R?be, C., Timmermann, B. ... Willich, N. (2011). Hypothyroidism after Head-and-Neck Radiotherapy in Children and Adolescents: Preliminary Results of the "Registry for the Evaluation of Side Effects after Radiotherapy in Childhood and Adolescence" (RiSK). International Journal of Radiation Oncology Biology Physics, 81(5), 787-791. doi: 10.1016/j.jirobp.2010.10.037.

[7] Charnosh, S. M. (2007). The comparative characteristic of three experimental models of hypothyroidism. Visnyk naukovykh doslidzhen, 2, 113-115.

[8] Ciavarella, D. (2014). Influence of vision on masticatory muscles function: surface electromyographice valuation. Annalidi Stomatologia, 2, 61-65.

[9] Dayan, C. M., \& Panicker, V. (2013). Thyroid hormones association with depression. Eur. Thyroid. J., 2, 168-179. doi: $10.1159 / 000353777$.

[10] Didushko, O. M. (2014). Age-specific peculiarities of lipid metabolism in patients with manifested hypothyroidism. Archive of clinical medicine, 20(1), 21-23.

[11] Faure, P., Oziol, L., Artur, Y., \& Chomard, P. (2004). Thyroid hormone (T3) and its acetic derivative (TA3) protect lowdensity lipoproteins from oxidation by different mechanisms. Biochimie, 86, 411-418. doi: 10.1016/j.biochi.2004.04.009.

[12] Goncharov, O. A. (2011). Lipid-lowering and pleiotropic effects of atorvastatin in women with autoimmune thyroiditis. Liky Ukrayiny, 6, 96-98.

[13] Guerrero, M., Rialp, J., \& Urbano, D. (2008). The Impact of Desirability and Feasibility on Entrepreneurial Intentions: A Structural Equation Model. International Entrepreneurship Management Journal, 4, 35-40. doi: 10.1007/s11365-0060032-x.

[14] Jiskra, J. (2001). Changes in muscle tissue in hypothyroidism. Vnitr. Lek., 47(9), 609-612.

[15] Kerimov, E. E. (2009). The metabolic and structural changes in periodontal tissue in patients with hypothyroidism. Georgian Med. News, 177, 23-27.

[16] Kim, S. K., Kim, S. H., \& Park, K. S. (2009). Regression of the increased common carotid artery-intima media thickness in subclinical hypothyroidism after thyroid hormone replacement. Endocr. J., 56(6), 753-758.

[17] Konnov, V. V., Lepilin, A. V., Bagarjan, E. A., \& Arushanjan, A. R. (2011). Funkcionalnoe sostojanie zhevatelnyh myshc $u$ pacientov s perelomami nizhnej cheljusti po dannym elektromiografii. Abstracts are presented in materials $\mathrm{XV}$ Mezhdunar. nauch. konf. "Zdorovesemi - XXI vek", Torremolinos (pp. 11-13). Torremolinos, Ispanija: Perm': OT i DO.

[18] Kotelnikov, A. I., Tatiyanenko, L. V., Vystorop, I. V., Dobrokhotova, O. V., \& Pikhtelev, I. Yu. (2016). The effect of cyclic hydroxamic acids on the activity of $\mathrm{Ca}^{2+}$ ATPase of the sarcoplasmic reticulum and cyclic guanosine monophosphate phosphodiesterase. Rossiyskiy bioterapevticheskiy zhurnal, 3, 23-27.

[19] Kulimbetov, M. T., Rashitov, M. M., \& Saatov, T. S. (2009). Simulation of experimental hypothyroidism due to natural chronic iodine deficiency in the diet. International Endocrinological Journal, 2(20), 22-27.

[20] McCarthy, H. D. (2013). Skeletal muscle mass reference curves for children and adolescents. Pediatr. Obes., 18, 45-58. doi: 10.1111/j.2047-6310.2013.00168.x.

[21] McNeil, C. J. (2013). Testing the excitability of human motoneurons. Front. Hum. Neurosci., 7, 1-9. doi: 10.3389/ fnhum.2013.00152

[22] Mi, Y. F., Li, X. Y., Tang, L. J. Lu, X. C., Fu, Z. Q., \& Ye, W. H. (2009). Improvement in cardiac function after sarcoplasmic reticulum $\mathrm{Ca}^{2+}$-ATPase gene transfer in a beagle heart failure model. Chin. Med. J. (Engl), 122(12), 1423-1428.

[23] Obata, H. (2014). Modulation between bilateral legs and within unilateral muscle synergists of postural muscle activity changes with development and aging. Exp. Brain. Res., 232(1), 1-11. doi: 10.1007/s00221-013-3702-2.

[24] Onigata, K. (2014). Thyroid hormone and skeletal metabolism. Clin. Calcium, 24(6), 821-827. doi: CliCa1406821827.

[25] Rush, J. M., Danzi, S., \& Klein, I. (2006). Role of thyroid disease in the development of statin-induced myopathy. Endocrinologist., 16, 279-285. Doi: 10.1097/ 01.ten.0000240960.40281.2b

[26] Salman, R. (2008). The influence of age on the relationship between subclinical hypothyroidism and ischemic heart disease: a metaanalisis. J. Clin. Endocrinol. Metabol., 93(8), 59-67. doi: 10.1210/jc.2008-0167.

[27] Samsonova, L. N., \& Kasatkina, E. P. (2007). Standards for the level of thyroid-stimulating hormone in the blood: modern state of the problem. Endocrinology problems, 539(6), 40-43.

[28] Sorokina, N. D., Gioeva, Yu. A., Selitsky, G. V., \& Markovtseva, M. A. (2016). Neurophysiological aspects of the study of functional disorders in the maxillofacial area. Rossiyskiy meditsinskiy zhurnal, 22(2), 98-104.

[29] Strongin, L. G., Nekrasova, T. A., Ledentsova, O. W., Kasakova L. V., \& Lukushkina, A. Y. (2012). Dyslipidemia and endothelial dysfunction in patients with the mildest hypothyroidism: relationship to $\mathrm{TSH}$ values and levothyroxine treatment. Abstracts are presented in book of Abstracts 36-th annual meeting of the European Thyroid Association (ETA), Pisa ( $p$. 80). Pisa: [2012].

[30] Tambovseva, R. V. (2010). Growth and development of skeletal muscles boys. Int. Abstracts are presented in materials symposium "Biological Motility from Fundamental Achievements to Nanotechnologies", Pushchino (pp. 276-278). Pushchino: [w.p.].

[31] Zahid, T. M., Wang, B. Y., \& Cohen, R. E. (2011). The effects of thyroid hormone abnormalities on periodontal disease status. J. Int. Acad. Periodontol., 13(3), 80-85.

\section{МОРФОФУНКЦІОНАЛЬНІ ЗМІНИ СТРУКТУРНИХ КОМПОНЕНТІВ ЖУВАЛЬНИХ М'ЯЗІВ СТАТЕВОЗРІЛИХ ТВАРИН ПРИ МЕРКАЗОЛІЛІНДУКОВАНОМУ ГІПОТИРЕОЗІ}

\section{Саган H.T.}

Ураження м'язової системи є одним з частих ускладнень при захворюваннях щитоподібної залози, однак на сьогодні немає одностайного погляду на морфофункціональні зміни жувальних м'язів при гіпотиреозі. Метою даного дослідження було встановити особливості структурної організації власне жувального та бічного крилоподібного м'язів статевозрілих щурів на різних етапах експериментально змодельованого гіпотиреозу. Дослідження виконували на жувальних м'язах статевозрілих щурів-самців на 14, 21, 28 добу розвитку мерказоліліндукованого гіпотиреозу. Використовували наступні методи дослідження: 
ін'єкційний метод дослідження кровоносного русла жувальних м'язів; гістологічне дослідження кровоносних судин та тканинних елементів жувальних м'язів; електронно-мікроскопічне дослідження; морфометричний аналіз: середнє значення просвіту кровоносних судин та товщина їх стінки, кількість капілярів в 1 мкм² поперечного перерізу м'язового волокна, кількість капілярів, які припадають на одне м'язове волокно, процентне співвідношення окисних м'язових волокон (ОМВ), окисно-гліколітичних (ОГМВ), гліколітичних (ГМВ), середня площа м'язового волокна; біохімічні методи; статистичний аналіз проводили за допомогою програмного забезпечення RV.3.0. Про розвиток гіпотиреозу свідчить зменшення гормонів щитоподібної залози в крові. На 14 добу експерименту в артеріальному руслі при ін'єкції паризькою синьою у жувальних м'язах відмічається дефрормація судинного рисунка. Кількість гемокапілярів зменшується. Субмікроскопічно відмічається набряк цитоплазми ендотеліоцитів. У м'язових волокнах поперечна посмугованість порушена, збільшувалась площа їх поперечного перерізу, в ендомізії спостерігається розширення та вакуолізація. Було встановлено зміну в кількісному розподілі всіх типів волокон (зменшувалася кількість ОГМВ і ОМВ та збільшувалася кількість ГМВ). На ультрамікроскопічному рівні спостерігалися виражені зміни в усіх типах м'язових волокон, особливо в ГМВ та ОМВ власне жувального м'яза. На 21 добу встановлено значну деформацію судинного рисунку зі зменшенням просвіту артерій та збільшенням просвіту вен. Продовжує зменшуватися кількість гемокапілярів. Ультраструктурно в ендотеліоцитах гемокапілярів жувальних м'язів прогресують набрякові зміни. У м'язових волокнах спостерігається втрата поперечної посмугованості та їх набряк. Зберігається тенденція до зменшення кількості ОГМВ і ОМВ та збільшення кількості ГМВ. На ультрамікроскопічному рівні виражені зміни в усіх типах волокон, особливо у власне жувальному м'язі. На 28 добу мерказоліліндукованого гіпотиреозу зміни в судинному руслі та у м'язових волокнах прогресують. Описані морфологічні зміни асоціюють із динамікою мікроелементного складу. Таким чином, при мерказоліліндукованому гіпотиреозі у жувальних м'язах спостерігаються набрякові зміни як $в$ судинному руслі так і в м'язових волокнах. Причому зміни поглиблюються в залежності від терміну експерименту.

Ключові слова: гіпотиреоз, м'язове волокно, онтогенез, гемомікроциркуляторне русло.

\section{МОРФОФУНКЦИОНАЛЬНЫЕ ИЗМЕНЕНИЯ СТРУКТУРНЫХ КОМПОНЕНТОВ ЖЕВАТЕЛЬНЫХ МЫШЦ ПОЛОВОЗРЕЛЫХ ЖИВОТНЫХ ПРИ МЕРКАЗОЛИЛИНДУЦИРОВАННОМ ГИПОТИРЕОЗЕ \\ Саган Н.T.}

Поражения мышечной системы являются одним из частых осложнений при заболеваниях щитовидной железы, однако сегодня нет единодушного взгляда на морфофункциональные изменения жевательных мыши при гипотиреозе. Целью данного исследования было установить особенности структурной организации собственно жевательной и боковой крыловидной мышцы половозрелых крыс на разных этапах экспериментально смоделированного гипотиреоза. Исследование выполняли на жевательных мышцах половозрелых крыс-самцов на 14, 21, 28 сутки развития мерказолилиндуцированного гипотиреоза. Использовали следующие методы исследования: инъекционный метод исследования кровеносного русла жевательных мыши; гистологическое исследование кровеносных сосудов и тканевых элементов жевательных мышц; электронно-микроскопическое исследование; морфометрический анализ: среднее значение просвета кровеносных сосудов и толщина их стенки, количество капилляров в 1 мкм² поперечного сечения мышечного волокна, количество капилляров, приходящихся на одно мышечное волокно, процентное соотношение окислительных мышечных волокон (ОМВ), окислительно-гликолитических (ОГМВ) и гликолитических (ГМВ), средний размер мышечного волокна; биохимические методы; статистический анализ проводили с помощью программного обеспечения RV.3.0. O развитии гипотиреоза свидетельствует уменьшение гормонов щитовидной железы в крови. На 14 сутки эксперимента в артериальном русле при инъекции парижской синей в жевательных мышцах отмечается деформация сосудистого рисунка. Количество гемокапилляров уменьшается. Субмикроскопически отмечается отек цитоплазмы эндотелиоцитов. В мышечных волокнах поперечная исчерченность нарушена, увеличивалась площадь их поперечного сечения, наблюдается расширение и вакуолизация эндомизия. Было установлено изменение в количественном распределении всех типов волокон (уменьшалось количество ОГМВ и ОМВ и увеличивалось количество ГМВ). На ультрамикроскопическом уровне наблюдались выраженные изменения во всех типах мышечных волокон, особенно в собственно жевательной мышце. На 28 сутки мерказолилиндуцированного гипотиреоза изменения в сосудистом русле и в мышечных волокнах прогрессируют. Описанные морфологические изменения ассоциируют с динамикой микроэлементного состава. Таким образом, при мерказолилиндуцированом гипотиреозе в жевательных мышиах наблюдаются отечные изменения как в сосудистом русле, так и в мышечных волокнах. Причем изменения усугубляются в зависимости от срока эксперимента.

Ключевые слова: гипотиреоз, мышечное волокно, онтогенез, гемомикроциркуляторное русло. 